\title{
PERAN DAN TANGGUNG JAWAB PEMERINTAH DAERAH DALAM PENATAAN PEDAGANG KAKI LIMA (PKL) DI KABUPATEN KARAWANG
}

\author{
M. Gary Gagarin Akbar \\ Email: gary.akbar@ubpkarawang.ac.id \\ Universitas Buana Perjuangan Karawang
}

\begin{abstract}
Abstrak
Pedagang Kali Lima (PKL) merupakan fenomena yang ada di seluruh wilayah di Indonesia. Kehadiran PKL seringkali dipandang negatif oleh masyarkat karena dianggap menganggu lalu lintas dan penggunaan trotoar sebagai tempat untuk berjualan. Untuk itu dibutuhkan peran dari pemerintah dalam rangka melakukan penataan terhadap PKL di Kabupaten Karawang. Rumusan masalah dalam penelitian ini adalah bagaimana peran dan tanggung jawab pemerintah daerah dalam penataan pedagang kaki lima $(P K L)$ di kabupaten karawang. Metode penelitian ini menggunakan metode kualitatif dengan metode pendekatan yuridis empiris yaitu mengelaborasikan antara studi kepustakaan dengan data-data empiris di lapangan. Hasil penelitian ini yaitu peran dan tanggung jawab pemerintah daerah Kabupaten Karawang sangat terlihat dari ketentuan-ketentuan yang ada dalam Peraturan daerah Kabupaten Karawang Nomor 4 Tahun 2015 tentang Penataan dan Pemberdayaan Pedagang Kaki Lima. Peran dan tanggung jawab pemerintah daerah antara lain menyiapkan lokasi bagi PKL untuk berjualan sesuai dengan tempat dan waktu, mengarahkan PKL untuk melakukan pendaftaran di Dinas terkait, Pemberdayaan PKL, melakukan monitoring dan evaluasi terhadap penataan dan pemberdayaan $P K L$, dan pembinaan dan pengawasan terhadap PKL.
\end{abstract}

Kata Kunci: Pedagang Kaki Lima (PKL),

Upaya Pemerintah, Asas Legalitas

\begin{abstract}
Street Vendors are a phenomenon that exists in all regions in Indonesia. The presence of street vendors is often viewed negatively by the community because it is considered to interfere with traffic and the use of sidewalks as a place to sell. For this reason, the role of the government is needed in order to organize the street vendors in Karawang Regency. The formulation of the problem in this study is how the roles and responsibilities of the local government in structuring street vendors in Karawang district. This research method uses a qualitative method with an empirical juridical approach method that is elaborating between library studies with empirical data in the field. The results of this study are the roles and responsibilities of the Karawang regency government are very visible from the provisions contained in the Karawang Regency Regional Regulation the area of Karawang Number 4 of 2015 on Arrangement and Empowerment of Street Vendors. Roles and responsibilities of the local government, among others, prepare locations for street vendors to sell according to place and time, direct street vendors to register in related offices, Empower street vendors, conduct monitoring and evaluation of structuring and empowering street vendors, and fostering and monitoring street vendors.
\end{abstract}

Keyword: Street vendors, Government efforts, The Principle of legality 


\section{PENDAHULUAN}

Negara Indonesia memiliki tujuan utama sebagaimana termuat dalam Pembukaan Undang-Undang Dasar Negara Republik Indonesia Tahun 1945 alinea ke-IV (keempat) yaitu salah satunya untuk memajukan kesejahteraan umum. Pembangunan dalam segala bidang menjadi penting dilaksanakan untuk memajukan kesejahteraan umum bagi masyarakat. Kesejahteraan umum diartikan sebagai keseluruhan prasyarat sosial yang memungkinkan atau mempermudah manusia mengembangkan semua nilainya merupakan suatu kondisi kehidupan sosial yang diperlukan agar setiap individu, keluarga, dan kelompok masyarakat dapat mencapai keutuhan atau perkembangan yang lebih utuh dan cepat yang terdiri atas syarat-syarat yang harus dipenuhi agar masyarakat merasa sejahtera

Keberadaan hukum dalam masyarakat, sebenarnya tidak hanya dapat diartikan sebagai sarana untuk menertibkan kehidupan masyarakat, melainkan juga dijadikan sarana yang

\footnotetext{
${ }^{1}$ Marwan Mas, Pengantar Ilmu Hukum, Cet.1 Ghalia Indonesia, Bogor, 2014, hlm. 82.
}

mampu mengubah pola pikir dan pola perilaku warga masyarakat. perubahan kehidupan sosial warga masyarakat yang semakin kompleks, juga mempengaruhi bekerjanya hukum dalam mencapai tujuannya. Oleh karena itu, pembuatan hukum seharusnya mampu mengeliminasi setiap konflik yang diperkirakan akan terjadi di dalam masyarakat. ${ }^{1}$

Karawang merupakan wilayah yang terkenal dengan sebutan "Kota Lumbung Padi" karena sebagian besar terhampar daerah persawahan yang sangat luas. Namun, sejak era tahun 2000-an Karawang mengalami pergeseran yang mana sebelumnya terkenal dengan sebutan Kota Lumbung Padi menjadi "Kota Industri”. Hal tersebut disebabkan Karawang menjadi salah Satu Kawasan Industri terluas di Asia Tenggara. Perubahan tersebut mengakibatkan terhadap kehidupan masyarakat di Karawang menjadi berkembang dengan sangat Pesat.

Kehadiran berbagai macam perusahaan pada faktanya berdampak positif terhadap peningkatan kesejahteraan masyarakat Karawang. 
Tetapi, di sisi yang lain banyaknya perusahaan mengakibatkan Karawang menarik minat para pendatang dari luar daerah untuk datang. Sehingga, pada akhirnya berdampak pada kehidupan sosial ekonomi masyarakat karena para pendatang tidak seluruhnya mampu terserap di Perusahaan. Kehidupan masyarakat yang pesat tersebut kemudian mengakibatkan munculnya Pedagang Kaki Lima (PKL).

Pedagang kaki lima atau disingkat PKL adalah istilah untuk menyebut menjajakan dagangan yang melakukan kegiatan komersial di atas daerah milik jalan atau trotoar yang seharusnya diperuntukkan untuk pejalan kaki (pedestrian). Ada pendapat yang menggunakan istilah PKL untuk pedagang yang menggunakan gerobak. Istilah itu sering diartikan demikian karena jumlah kaki pedagangnya ada lima. Lima kaki tersebut adalah dua kaki pedagang ditambah tiga (yang sebenarnya adalah tiga roda, atau dua roda dan satu kaki kayu). Menghubungkan jumlah kaki dan roda dengan istilah kaki lima adalah pendapat yang mengada-ada dan tidak sesuai dengan sejarah. Pedagang bergerobak yang berada secara statis di trotoar adalah fenomena yang cukup baru, sebelumnya PKL didominasi oleh pedagang pikulan (penjual cendol, pedagang kerak telor) dan gelaran (seperti tukang obat jalanan).

Permasalahan mengenai PKL di setiap daerah memang sangat kompleks. Di satu sisi kehadiran PKL membangkitkan perekonomian masyarakat menengah ke bawah dan membantu mengurangi angka pengangguran. Namun, di sisi yang lain kehadiran PKL juga ada dampak negatif bagi ketertiban dan keindahan kota karena PKL berjualan tidak pada tempatnya. Misalnya ada PKL yang berjualan di trotoar yang menyebabkan terganggunya hak pejalan kaki. Kemudian, PKL juga banyak yang menggunakan bahu jalan untuk berjualan sehingga mengakibatkan kemacetan lalu lintas serta berjualan di tempat-tempat yang sebenarnya telah dilarang oleh Pemerintah Daerah. Berdasarkan uraian tersebut di atas, maka penulis tertarik untuk melakukan penelitian dengan judul "PERAN DAN

TANGGUNG JAWAB PEMERINTAH DAERAH DALAM PENATAAN PEDAGANG KAKI 
LIMA (PKL) DI KABUPATEN KARAWANG".

\section{PERMASALAHAN}

Berdasarkan hal-hal yang telah dijelaskan di atas, maka muncul suatu rumusan masalah yaitu bagaimana peran dan tanggung jawab pemerintah daerah dalam penataan pedagang kaki lima (PKL) di kabupaten karawang?

\section{METODE PENELITIAN}

Metode pendekatan yang digunakan dalam penelitian ini adalah yuridisnormatif. Selain itu penelitian ini juga menggunakan pendekatan studi lapangan sebagai pendukung berdasarkan ruang lingkup dan identifikasi masalah yang ada. Hal ini dimaksudkan agar penelitian ini sejauh mungkin dapat mengetahui mengenai urgensi pembaharuan kebijakan tentang perlindungan hukum terhadap guru di Indonesia secara detail yang bersumber dari beberapa aspek.

Untuk mengkaji pokok permasalahan, penelitian ini mempergunakan metode penelitian hukum normatif. Dengan meneliti bahan pustaka yang ada. Salah satunya dengan pendekatan perundang-undangan. Karena yang akan diteliti adalah berbagai aturan hukum yang menjadi fokus sekaligus tema sentral suatu penelitian. Penelitian ini akan lebih menitikberatkan pada penelitian hukum normatif. Dengan menyesuaikan diri dengan ruang lingkup dan identifikasi masalah yang telah dikemukakan diatas. Pendekatan yang bersifat yuridisnormatif tersebut akan dilakukan dengan mempergunakan bahan hukum primer, bahan hukum sekunder dan bahan hukum tersier.

\section{HASIL DAN PEMBAHASAN}

A. Asas Legalitas dan Otonomi Daerah Sebagai Dasar Pemerintah Daerah dalam

\section{Melakukan Tindakan Hukum}

Ketika membahas mengenai kebijakan pemerintah terutama berkaitan dengan permasalahan untuk mengatur suatu kelompok masyarakat tertentu yang dalam hal ini adalah PKL, maka kita harus mengacu pada asas legalitas dan otonomi daerah sebagai landasan utama bagi pemerintah dalam melakukan tindakan hukum.

Asas legalitas merupakan salah satu prinsip utama yang menjadi dasar dalam penyelenggaraan pemerintah dan kenegaraan yang berbasis hukum. Asas 
legalitas menjadi dasar legitimasi tindakan pemerintah dan jaminan perlindungan dari hak-hak rakyat. ${ }^{2}$ Asas legalitas berarti setiap tindakan yang akan diambil oleh pemerintah atau penyelenggara negara harus berdasarkan atas hukum. Hal tersebut dimaksudkan agar pemerintah dapat memberikan kepastian hukum dan kesamaan perlakuan terhadap masyarakat.

Menurut UU Nomor 23 tahun 2014 tentang Pemerintahan Daerah Pasal 1 angka 6 menyatakan bahwa "Otonomi daerah adalah hak, wewenang, dan kewajiban daerah otonom untuk mengatur dan mengurus sendiri urusan pemerintahan dan kepentingan masyarakat setempat sesuai dengan peraturan perundang-undangan."

Otonomi daerah merupakan esensi pemerintahan desentralisasi. Istilah otonomi daerah berasal dari penggalan dua kata bahasa Yunani, yakni autos yang berarti sendiri dan nomos yang berarti undang-undang. ${ }^{3}$ Menurut Busrizalti, otonomi daerah adalah upaya

\footnotetext{
2 M. Gary Gagarin Akbar, Hukum Administrasi Negara, FBIS Publishing, Karawang, 2018, hlm. 31 .

3 Ni'matul Huda, Perkembangan Hukum Tata Negara, Perdebatan \& Gagasan Penyempurnaan, Cetakan Pertama, FH UII Press, Yogyakarta, 2014, hlm.409.
}

untuk mewujudkan demokratisasi dimana aspek aspirasi rakyat dalam hal ini kepentingan yang terdapat di tiap-tiap daerah terakomodir dengan baik. Otonomi daerah memungkinkan "kearifan lokal" masing-masing daerah dapat berjalan sebagaimana mestinya sesuai prakarsa dan inisiatif masyarakat di daerah. ${ }^{4}$ Otonomi daerah adalah suatu keadaan yang memungkinkan daerah mengaktualisasi segala potensi terbaik yang dimilikinya secara optimal. Untuk mewujudkan keadaan tersebut, berlaku proposisi bahwa pada dasarnya segala persoalan sepatutnya diserahkan kepada daerah untuk mengidentifikasikan, merumuskan, dan memecahkan, kecuali untuk persoalan-persoalan yang memang tidak mungkin diselesaikan oleh daerah itu sendiri dalam perspektif keutuhan negara-bangsa. Bukan sebaliknya, yaitu proposisi bahwa seluruh persoalan paada dasarnya harus diserahkan kepada pemerintah pusat, kecuali untuk persoalan tertentu yang telah dapat ditangani oleh daerah. ${ }^{5}$

\footnotetext{
4 H.M. Busrizalti, Hukum Pemda Otonomi Daerah dan Implikasinya, Cetakan Pertama, Total Media, Yogyakarta, 2013, hlm.71.

5 Faisal H. Basri, Otonomi Atau Federalisme, Cetakan Pertama, Sinar Harapan, Jakarta, 2000, hlm. 160.
} 
Otonomi daerah merupakan pemberian kebebasan untuk mengurus rumah tangga sendiri, tanpa mengabaikan kedudukan pemerintah daerah sebagai aparat pemerintah pusat untuk menyelenggarakan urusan-urusan yang ditugaskan kepadanya. Oleh sebab itu, usaha membangun keseimbangan harus diperhatikan dalam konteks hubungan kekuasaan antara pusat dan daerah. Artinya daerah harus dipandang dalam dua kedudukan, yaitu sebagai organ daerah untuk melaksanankan tugas-tugas otonomi dan sebagai agen pemerintah pusat untuk menyelenggarakan urusan pemerintah pusat di daerah. ${ }^{6}$

\section{B. Peran Dan Tanggung Jawab Pemerintah Daerah Dalam Penataan Pedagang Kaki Lima} (PKL) Di Kabupaten Karawang

Dalam Undang-undang Nomor 23 Tahun 2014 tersebut, urusan pemerintahan dibagi menjadi 3, yaitu urusan pemerintahan absolut; urusan pemerintahan konkuren; dan urusan pemerintahan umum. Urusan pemerintahan konkuren adalah urusan pemerintahan yang dibagi antara pemerintah pusat dan daerah provinsi dan daerah kabupaten/kota dan urusan pemerintahan konkuren yang diserahkan ke daerah menjadi dasar pelaksanaan otonomi daerah. adapun urusan pemerintahan konkuren yang menjadi kewenangan daerah terdiri atas urusan pemerintahan wajib dan urusan pemerintahan pilihan. Di dalam UndangUndang Nomor 23 Tahun 2014 itulah prinsip-prinsip otonomi daerah dipertegas. Berkaitan dengan persoalan pelayanan dasar, kedua undang-undang tersebut sama-sama memberikan amanah kepada pemerintah untuk mengurusi dan memperhatikan pengelolaan di bidang pelayanan dasar seperti terkait masalah ketertiban dan kepentingan masyarakat. Melalui Undang-Undang Nomor 23 Tahun 2014, kewenangan pemerintah daerah untuk mengurusi persoalan perhubungan maupun ketertiban masyarakat seperti yang terdapat di dalam Pasal 11, Pasal 12, dan Pasal 18. Dari berbagai ketentuan tersebut, dikatakan bahwa

\footnotetext{
${ }^{6}$ Moh. Mahfud MD, Politik Hukum di Indonesia, Cetakan Kelima, Rajawali Pers, Jakarta, 2012, hlm. 95.
} 
pada intinya pemerintah daerah memiliki kewenangan dalam urusan kongkruen yang merupakan pembagian antara pemerintah pusat dan pemerintah daerah yang salah satunya adalah dibidang pelayanan dasar terkait perhubungan, penataan ruang, maupun ketertiban masyarakat. Urusan pemerintah kongkruen di bidang tersebut merupakan urusan pemerintahan pilihan yang pelaksanaannya didasarkan pada prinsip akuntabilitas, efisiensi, dan eksternalitas, serta kepentingan strategis nasional. Hal ini menjadi dasar bagi pemerintah daerah dalam mengatur penataan berkaitan dengan PKL.

Dalam rangka menyelesaian permasalahan terkait PKL di Kabupaten Karawang, Pemerintah Daerah mengeluarkan kebijakan yaitu Peraturan Daerah Kabupaten Karawang Nomor 4 Tahun 2015 tentang Penataan dan Pemberdayaan Pedagang Kaki Lima. Dikeluarkannya Peraturan Daerah Kabupaten Karawang tersebut dapat dikaitkan dengan teorinya Roscoe Pound yaitu hukum sebagai alat rekayasa sosial

7 M. Gary Gagarin Akbar, Pengantar Ilmu Hukum, FBIS Publishing, Karawang, 2018, hlm. 13 . masyarakat (law as a tool of social engineering).

Hukum sebagai sarana perekayasa sosial (mengubah masyarakat) adalah untuk menciptakan perubahanperubahan dalam masyarakat menuju kemajuan yang terencana atau direncanakan. Hal tersebut artinya memiliki arah untuk menata kembali kehidupan masyarakat secara terencana sesuai tujuan pembangunan bangsa, kehidupan masyarakat sampai kini ternyata selalu mengalami perubahan atau dinamika yang sangat pesat. Hal ini menunjukkan bahwa hampir tidak ada kelompok masyarakat di dunia yang kehidupan sosialnya tetap statis. Masyarakat manapun dan dimanapun pasti mengalami perubahan, baik karena pengaruh dari luar maupun yang akan terjadi sendirinya dalam masyarakat yang bersangkutan. ${ }^{7}$ Kemudian, social engineering dimaksudkan agar hukum dijadikan sebagai instrumen rekayasa sosial untuk mengubah masyarakat ke tujuan yang lebih baik. fungsi hukum sebagai sarana perekayasa sosial adalah fungsi untuk menciptakan perubahan- 
perubahan kehidupan sosial masyarakat ke arah kemajuan.

Menurut Pasal 1 angka 8 Peraturan Daerah Kabupaten Karawang Nomor 4 Tahun 2015 tentang Penataan dan Pemberdayaan Pedagang Kaki Lima menyatakan bahwa Pedagang Kaki Lima yang selanjutnya disingkat PKL adalah pelaku usaha yang melakukan usaha perdagangan dengan menggunakan sarana usaha bergerak maupun tidak bergerak, menggunakan prasarana kota, fasilitas sosial, fasilitas umum, lahan dan bangunan milik pemerintah dan/atau swasta yang bersifat sementara/tidak menetap.

Selanjutntya, pada Pasal 2 Peraturan Daerah Kabupaten Karawang Nomor 4 Tahun 2015 menyatakan bahwa Bupati wajib melakukan penataan dan pemberdayaan PKL. Hal tersebut menegaskan bahwa pemerintah daerah wajib memperhatikan keberadaan PKL. Kemudian, di dalam Peraturan daerah tersebut juga terdapat ketentuan mengenai kewenangan pemerintah daerah untuk melakukan penataan dan pemberdayaan PKL. Peraturan daerah ini menjadi payung hukum bagi pemerintah daerah untuk menyelesaikan persoalan tentang PKL.
Keberadaan PKL tidak bisa dianggap negatif saja, namun keberadaan PKL dapat membangkitkan perekonomian rakyat khususnya di Kabupaten Karawang. Sebagaimana tujuan Negara yang terdapat dalam Undang-Undang Dasar Negara Republik Indonesia yang menyatakan bahwa salah satu tujuan negara adalah "memajukan kesejahteraan umum". Hal ini menegaskan bahwa pemerintah harus mampu mewujudkan tujuan tersebut.

Jika kita mengacu pada Peraturan Daerah Kabupaten Karawang Nomor 4 Tahun 2015 terlihat bahwa ada upaya pemerintah untuk melindungi, menata, dan memberdayakan PKL di Kabupaten Karawang. Peran dan tanggung jawab yang dilakukan oleh pemerintah daerah yaitu antara lain. Pertama, pemerintah daerah menyiapkan lokasi bagi PKL untuk berjualan sesuai dengan tempat dan waktu. Hal ini tentu saja upaya preventif dari pemerintah daerah untuk mencegah PKL menggunakan tempattempat yang dilarang untuk berjualan. Pemerintah Kabupaten Karawang menerapkan zonasi untuk para PKL yaitu Zona Hijau yang berarti diperbolehkan untuk berjualan, Zona Kuning berarti diperbolehkan berjualan 
berdasarkan waktu tertentu, dan Zona Merah yang berarti kawasan yang dilarang untuk berjualan.

Kedua, mengarahkan PKL untuk melakukan pendaftaran di Dinas terkait. Hal ini bertujuan agar pemerintah dapat mengetahui dan mengontrol jumlah PKL yang ada di Kabupaten Karawang. Ketiga, Pemberdayaan PKL. Tujuannya agar PKL dapat meningkatkan pendapatan dan kegiatan usahanya melalui peningkatan kemampuan berusaha, fasilitas akses permodalan, pembinaan dan bimbingan teknis kepada PKL. Peran penting pemerintah dalam hal ini akan berdampak luas terhadap keberlangsungan usaha PKL karena apabila diberikan akses permodalan, kemudian diberikan pembinaan, dan bimbingan teknis diharapkan ke depannya PKL dapat mengembangkan usahanya.

Keempat, melakukan monitoring dan evaluasi terhadap penataan dan pemberdayaan PKL. Monitoring dan evaluasi harus dilakukan oleh pemerintah secara berkelanjutan agar masyarakat menjadi tertib dan tidak memberikan ruang bagi masyarakat khususnya PKL untuk melanggar ketentuan yang telah ditetapkan.
Sehingga PKL harus diarahkan sedemikian rupa agar tetap pada koridor hukum yang berlaku.

Kelima, pembinaan dan pengawasan terhadap PKL. Hal tersebut termasuk kewenangan pemerintah untuk memberikan sosialisasi kepada PKL secara periodik agar PKL dapat memahami kebijakan apa saja yang dilarang dan diperbolehkan oleh pemerintah daerah. Pentingnya sosialisasi karena di dalam hukum ada asas hukum bahwa semua orang dianggap tahu hukum sehingga tidak ada alasan bagi masyarakat tidak patuh hukum karena merasa tidak tahu ada aturan yang telah diterapkan pemerintah.

Berdasarkan hal-hal tersebut diatas, dapat diketahui bahwa peran dan tanggung jawab pemerintah daerah Kabupaten Karawang sangat terlihat dari ketentuan-ketentuan yang ada dalam Peraturan daerah Kabupaten Karawang Nomor 4 Tahun 2015 tentang Penataan dan Pemberdayaan Pedagang Kaki Lima. Kebijakan yang telah dimiliki oleh pemerintah daerah tersebut harus mampu diimplentasikan dengan baik oleh Pemerintah daerah agar PKL dan masyarakat umum dapat merasakan dampak positifnya. Di dalam 
implementasinya, pemerintah daerah harus mampu bersikap tegas dan tidak tebang pilih. Untuk memaksimalkan peraturan tersebut, pemerintah daerah memberikan kewenangan kepada Satuan Polisi Pamong Praja sebagai penegak peraturan daerah untuk menertibkan, menata, dan menegakkan ketentuan yang ada di dalam peraturan daerah.

\section{KESIMPULAN}

Berdasarkan hasil penelitian dan pembahasan maka dapat disimpulkan penelitian ini sebagai berikut:

1. Asas legalitas merupakan prinsip terpenting yang harus ada pada setiap negara hukum. Pemerintah dalam melakukan tindakan hukum kepada warga negara harus berdasarkan pada peraturan perundang-undangan yang berlaku sehingga akan menghindari penyahgunaan wewenang dan perbuatan sewenang-wenang. Selain itu, pemerintah daerah mempunyai kewenangan untuk mengatur daerah sendiri berdasarkan otonomi daerah yang mana merupakan amanat dari UU No. 23 Tahun 2014 tentang Pemerintahan Daerah.
2. Peran dan tanggung jawab yang dilakukan oleh pemerintah daerah yaitu antara lain. Pertama, pemerintah daerah menyiapkan lokasi bagi PKL untuk berjualan sesuai dengan tempat dan waktu. Hal ini tentu saja upaya preventif dari pemerintah daerah untuk mencegah PKL menggunakan tempat-tempat yang dilarang untuk berjualan. Kedua, mengarahkan PKL untuk melakukan pendaftaran di Dinas terkait. Hal ini bertujuan agar pemerintah dapat mengetahui dan mengontrol jumlah PKL yang ada di Kabupaten Karawang. Ketiga, Pemberdayaan PKL. Tujuannya agar PKL dapat meningkatkan pendapatan dan kegiatan usahanya melalui peningkatan kemampuan berusaha, fasilitas akses permodalan, pembinaan dan bimbingan teknis kepada PKL. Keempat, melakukan monitoring dan evaluasi terhadap penataan dan pemberdayaan PKL. Kelima, pembinaan dan pengawasan terhadap PKL. Hal tersebut termasuk kewenangan pemerintah untuk memberikan sosialisasi kepada PKL secara periodik agar 
PKL dapat memahami kebijakan apa saja yang dilarang dan diperbolehkan oleh pemerintah daerah.

\section{DAFTAR PUSTAKA}

Faisal H. Basri, Otonomi Atau Federalisme, Cetakan Pertama, Sinar Harapan, Jakarta, 2000.

H.M. Busrizalti, Hukum Pemda Otonomi Daerah dan Implikasinya, Cetakan Pertama, Total Media, Yogyakarta, 2013.

Marwan Mas, Pengantar Ilmu Hukum, Cet.1, Ghalia Indonesia, Bogor, 2014.

Moh. Mahfud MD, Politik Hukum di Indonesia, Cetakan Kelima, Rajawali Pers, Jakarta, 2012.

Muhammad Gary Gagarin Akbar, Hukum Administrasi Negara, FBIS Publishing, Karawang, 2018.

, Pengantar Ilmu Hukum, FBIS Publishing, Karawang, 2018.

Ni'matul Huda, Perkembangan Hukum Tata Negara, Perdebatan \& Gagasan Penyempurnaan, Cetakan Pertama, FH UII Press, Yogyakarta, 2014.

\section{Peraturan Perundang-undangan}

Undang-Undang Dasar Negara Republik Indonesia Tahun 1945.
Undang-Undang Nomor 23 Tahun 2014 tentang Pemerintahan Daerah.

Peraturan Daerah Kabupaten Karawang Nomor 4 Tahun 2015 tentang Penataan dan Pemberdayaan Pedagang Kaki Lima. 